\title{
Textbooks in the historiography of recent economics
}

\author{
Yann Giraud ${ }^{1}$ \\ Draft 2.0 prepared for The Contemporary Historiography of Economics, edited by Till Düppe \\ and Roy Weintraub, Routledge, Forthcoming.
}

27 February 2018

\begin{abstract}
Textbooks are both neglected and at times overused as objects in the history of economics. They are neglected because most historians, borrowing from Kuhn, tend to regard them as passive receptacles of past knowledge, yet they are also overused as shortcuts to study the state of economic doctrine at a certain point in time. Looking at the existing historical literature that studies or uses textbooks, this chapter shows how a better understanding of the specific pedagogical and institutional environments in which textbooks operate can help build thicker and more accurate histories of the role they have played, not just in disseminating, but also in creating and transforming economic knowledge.
\end{abstract}

Author info: Yann Giraud is an Assistant Professor of economics at the University of CergyPontoise. His research deals with the role of visual representation in producing and disseminating economic knowledge, the history of US economics education in the twentieth century and, more recently, the relation between economics and engineering. Since 2010, he co-organizes the annual Conference on the History of Recent Economics (Hisreco).

\section{Introduction}

Economics textbooks can be encountered on the most unlikely of occasions. In an episode of the TV crime series Cold Case, the police detectives who try to solve an old murder case that happened in the early fifties interrogate a now eighty-years-old woman, who once knew the victim. In her twenties at the time when the murder happened, she was a submissive housewife, married to an abusive and unfaithful husband and looking for a freer, more independent life. That sense of freedom is exemplified in a flashback sequence in which she is seen reading the university book she is studying, A. Smith Pond's Elementary Economics.

\footnotetext{
${ }^{1}$ University of Cergy-Pontoise, ThEMA (UMR CNRS 8184).
} 
The latter was one of these textbooks that notoriously copied Samuelson's leading text Economics: An Introductory Analysis in appearance but were simplified for a mathematically untrained audience, for instance housewives such as the one we see in the episode, who might take evening classes at a women's college nearby. At the end of the episode, the textbook makes another appearance: now that the murderer has been caught, we see the old woman, relieved that the case has been solved, who decides to remember the past by skimming through that same Pond's text she has kept home for years as a representation of that life she was longing for but never managed to build for herself. ${ }^{2}$ Cold Case's screenwriters may not be perfect historians. They use a textbook first published in 1954 in a sequence that is supposed to occur in 1953. Yet, like good historians of economics - and of science - should do, they seem to have understood something about textbooks: that they are not just repositories of past knowledge, that they are used in certain contexts and sometimes hold a cultural significance that can exceed their sole academic value.

In this chapter, I do not argue that all contributions to - or using - economics textbooks should be as thick in their outlook as to encompass all of these cultural and societal aspects altogether. In fact, as we will see further, few if any existing contributions do - and this applies to my own work on this topic. Yet, what I want to stress is that a general lack of reflection on the role of textbooks in the discipline can lead to exceedingly thin accounts that consider this literature as a shortcut to study the state of economic doctrine at some point in time. This 'reductionist approach' to textbooks, as I call it, cannot be fully rewarding, as the idea of studying a whole field of knowledge through the choices made by some particular subgroup of authors and editors seems flawed from the start. In addition, the reductionist approach to textbooks seems to overlook the very reason why textbooks are used in the first place: as teaching aids, located in specific pedagogical and institutional environments although, as I will detail later on, some textbooks have also been used for other purposes. Therefore, it can be said that economics textbooks have been simultaneously overused and neglected as tools to study the history of economics.

Yet, my purpose here is not to lament over the current situation and what I want to suggest, by surveying the existing historical literature, is that there are many possibilities and untouched areas that future researchers may be interested in exploring by regarding textbooks as major elements in the material culture of past and present economists. In the next section, I

\footnotetext{
2 "Devil Music", Cold Case, Season 5, Episode 4 (2007). This textbook sequence was first brought to my attention by Loïc Charles' (2008) blog post, although at the time he misidentified the textbook as Samuelson's Economics. I subsequently wrote a blog post myself in response (Giraud 2011).
} 
will turn to the larger history of science by looking at how textbooks have been studied there. Although a few scholars have thought deeply about historiographical issues regarding textbooks, it is clear that, on the whole, textbooks still have low status in the field. In a second section, reviewing the history of economics literature, I will point to a number of historiographical issues and stress the similarities and divergences with what has been observed in the history of science. Finally, in the concluding section, I will try to outline a program for future research on economics textbooks. In the following, while I am mostly interested in the historiography of postwar economics, I will occasionally mention works that have addressed pre-WWII textbooks as a way to emphasize what is specific to the more recent period. Also, I must recognize that this chapter is mostly concerned with introductory and undergraduate texts: this is because the existing literature mostly focuses on those, something that future research will hopefully counterbalance in favor of the more technically sophisticated books used in graduate education.

\section{Textbooks in the larger history of science}

Historians of science have not necessarily reflected more on textbooks than historians of economics, as two recent historiographical essays (Vicedo 2012, Simon 2016) show. In his account, Josep Simon (2016) writes: "historians of science have shown a longstanding interest in textbooks, but it has not resulted in more and better studies displaying significant historiographical and methodological discussions (Simon 2016, p. 401).” He observes that most existing contributions still focus on textbooks written by major scientists, therefore ignoring the vast majority of textbooks written by lesser authors, including some of whom located neither in Europe nor in the United States whose work has been influential in shaping scientific disciplines in their home countries. Simon's main claim is that a better understanding of textbooks should contribute to highlight the truly international dimension of science and help reverse a number of national hierarchies commonly taken as granted by historians of science. Marga Vicedo's (2012) contribution expresses similar dissatisfaction with the existing historiography of scientific textbooks, arguing that most of the time historians have simply followed scientists' own lack of interest in them, as they consider them as "mere repositories for scientific knowledge". She attributes this ignorance to the "received view" of science diffusion, which considers science education - along with popular accounts and applications - as hierarchically inferior to knowledge creation, and takes Thomas Kuhn to task for treating textbooks as collections of exemplars whose sole role was to indoctrinate 
students into the dominant paradigm. ${ }^{3}$ Besides, sociologically inflected historians and philosophers of science who have dismantled the "received view" of knowledge production over the past two decades have focused more on laboratories and field research than on science education and textbooks, leaving this topic relatively untouched. ${ }^{4}$

However, both Vicedo and Simon show that the situation has been partially reversed in recent years, thanks to the emerging subfield of science education history. This literature has shown that textbooks are entrenched in pedagogical practices and that in order to understand how knowledge becomes standardized, it can be useful to start with classroom notes to unveil a number of features that are hidden in printed texts. Looking at the pedagogical uses of textbooks also helps understand what differentiates "textbooks" from "treatises" or "elements". Patiniotis (2006) asserts that while the English word "textbook" dates from 1730, its current meaning - i.e. "a book containing a systematic presentation of the principles of a subject or a collection of writings dealing with a specific subject" - coincides with the development of systematic scientific education in the nineteenth century. Therefore, a book is not a textbook by nature: influential treatises can become required readings in the classroom and acquire the status of textbooks even though they were not intended as such in the first place. The transformation of books into textbooks, Simon argues, is generally a circular process: the authority of textbooks comes from their use in the classroom and, reciprocally, some books become used in the classroom because of their authority, which comes from a great number of factors: the scientific credentials of the author, the efforts of the publishers or some external pedagogical authority for instance. More generally, Vicedo (2012, p. 85) identifies a number of threads that the historical study of textbooks has helped explore in recent years and should help explore further in the future: the use of textbooks in pedagogical and training practices; their role in shaping new disciplines and/or subfields of science; the development of ideas throughout time and space, the changing epistemological concerns in a field; the study of priority disputes; the study of external influences on science (religion, politics and business). That list is of course not meant to be exhaustive.

\footnotetext{
${ }^{3}$ See Kuhn's negative comments on textbooks in his 1959 lecture at the University of Utah (in Kuhn 1977: 2289): "Except in their occasional introduction, science textbooks do not describe the sorts of problems that the professional may be asked to solve and the variety of techniques available for their solution. Rather these books exhibit concrete problem solutions that the profession has come to accept as paradigms ... Nothing could be better calculated to produce 'mental sets' or Einstellungen ..."

${ }^{4}$ Vicedo is referring to the "diffusion model" described and criticized in Latour 1987.
} 
In practice, though, few historical contributions on textbooks deal with postwar social science, as most studies focus on a period ranging from the French revolution to the beginning of the $20^{\text {th }}$ century and on the natural sciences, chemistry being the only field that has been extensively analyzed following more than a decade of research (e.g. Lundgren and BensaudeVincent 2000, Bensaude-Vincent, Garcia-Belmar and Bertomeu-Sanchez 2003, Rocke 2010). They point to the mid-nineteenth century as the period of emergence of the textbook genre in these fields, following the development of national systems of secondary education and the appearance of a publishing industry to supply that market. Rocke's work on the role of visualization in the development of chemistry highlights the importance of August Kekulé's textbook Lehrbuch der organischen Chemie (1859-66) in the dissemination of the author's own representation of molecular structure - known as "sausage formulas" - and of his valence theory. Kékulé's fascicles emanated from his seminars and his graphic formulas adopted the same shape as the physical, wooden, molecular models he used there. Kékulé's text was immediately considered a success by his peers because of its author's high credentials as a scientist and due to the structure of Germany's higher education system. Most early reviewers of the texts had witnessed his teaching first hand because teaching took place in small laboratories, as higher education was still intended for an elite audience, so that teachers and students were on an almost equal footing.

One of the rare extensive investigations of textbooks in postwar science is that provided by Kaiser (2005) as part of his larger study of Feynman diagrams in physics. Kaiser's book is a rather extreme plea for the materialistic turn in the history of science, he argues that there is no such thing as "theoretical physics", and that in fact, even the most abstract developments in this field are rather the result of countless hours of dull calculation, allowed in part by the use of different instantiations of the Feynman diagram, a visual technique that permits the simplification of enormous systems of simultaneous equations. After narrating the first appearance of the diagram at a 1948 physics conference, Kaiser devotes most of his book to the subsequent dissemination and transformation of this diagram, looking at a wide array of teaching materials and textbooks. Kaiser shows that the early postwar period witnessed the rise of a "textbook age" in physics, mostly as a consequence of the G.I. Bill of Rights, which sparked an unprecedented rise in enrollments in science departments. As a result, science publishers were open to new materials, encouraging younger researchers to publish their course notes as soon as possible. Because all of these researchers were using different forms of Feynman diagrams and were all involved in frontier research, the resulting textbooks were far from standardized and, contrary to Kuhn's claim, did not look 
like repositories of "finished achievements". Feynman diagrams there had various shaped and were used in a variety of ways, most of that initially intended by their creator. Yet, Kaiser's analysis also yields some negative results: Feynman diagrams are not as disseminated in textbooks as in class notes and unpublished drafts and therefore textbooks do not fully reflect the upsurge in creativity generated by their appearance at the time. The reason is not just related to the high costs of introducing visuals into textbooks. It is just that when it comes to the new techniques, direct teaching proved more efficient than the use of printed materials. Graduate students had quickly become so used to the diagram that they could use them in their mind's eye, without having to resort to paper tools (Kaiser 2005: 279). A subsequent paper (Kaiser 2012) dealing with two specific physics textbooks, Gravitation (1973) and The Tao of Physics (1975), serves as an illustration that lines are blurry between textbooks and books, as a mix of authorial intent, publishing strategies, readers' response and critical reaction, transform them into highly successful essays. Although Kaiser details the numerous factors behind this transformation, he clearly regards these two books as "outliers", therefore undermining the significance of his own monograph to the larger history of postwar physics textbooks.

All in all, whereas recent works in the history of science have helped renew interest in textbooks and begun to ask interesting questions about them, existing contributions are still very fragmentary. Whereas it is obvious from the preceding paragraphs that a transdisciplinary study of science textbooks would be highly beneficial, most of the existing work has been done within discipline histories of science with little regard to what has been done in neighboring fields. Though specific, history of economics is no exception.

\section{The current historiography of economics textbooks}

As many commenters have noted (see for instance Fontaine 2016 and Weintraub 2016b), disciplinary history of economics differs from the larger history of science in that it is still vastly subjugated to the economics discipline as a whole, trying to look at past theories in order to settle current debates within the field. When it comes to textbooks, this subjugation translates into one specific genre of historical narratives that considers textbooks critically, looking at their apparent standardization in order to point to possible biases against innovative - often non-orthodox - ways of thinking in economics. However, this is only one among several ways historians of economics have used textbooks. In this section, I am depicting three other genres of narratives: the second uses a selection of textbooks as a way to reflect on 
the dissemination of ideas in the postwar period; the third studies some particular textbooks as part of larger biographical accounts; finally, the fourth points to the more active role that textbooks play in the shaping of economics departments.

\section{The over-representation of Samuelson's Economics}

Before I begin to detail these four narrative genres, however, I need to stress how over-represented Paul Samuelson's undergraduate textbook Economics is in all of these studies. ${ }^{5}$ In fact, with the exception of one paper on Joan Robinson's An Introduction to Modern Economics, which I will detail later in this section, Samuelson's textbook is the only postwar text having been the object of monographs. ${ }^{6}$ In addition, it is present in many contributions that use textbooks as data for the dissemination of ideas and. The reasons why Economics is so ubiquitous in these endeavors are quite obvious. First, the fact it was revised many times over the period makes it the perfect item for those who want to trace the development of a concept or tool over the second half of the twentieth century. Samuelson himself encouraged that kind of practice, writing in the fourteenth edition: "A historian of mainstream-economic doctrines, like a paleontologist who studies the bones and fossils in different layers of earth, could date the ebb and flow of ideas by analyzing how Edition 1 was revised to Edition 2 and, eventually, to Edition 14" (cited by Skousen 1997: 138). The second reason is the author's undisputable stature and influence over economics research in the postwar period. Historians of economics, who are still interested, in spite of some recent historiographical trends, in the study of 'great figures', would be inclined to follow his incantation.

To say that Economics is over-represented in the existing historical accounts is not to deny its impact. Described retrospectively by the author as part of "the revolutions that hit economic introductory textbooks half a century ago" (Samuelson 1997: 153), it is said to have "dominated the college classrooms for two generations" (Skousen 1997: 137). Kenneth Elzinga (1992) brings quantitative evidence to that claim, showing that Economics outsold all

\footnotetext{
${ }^{5}$ Now discontinued after nineteen editions, Samuelson's textbook was first published under the title Economics: an Introductory Analysis in 1948 before being shortened to Economics for its eighth edition (1970). The tenth edition (1976) was written with the help of MIT economic historian Peter Temin, who took care of the empirics. From the twelfth edition onward, William Nordhaus stepped in as Samuelson's co-author.

${ }^{6}$ Here, as the author of two published papers and one draft paper on the subject, I clearly must assume my part of the blame for this situation.
} 
other competitors until the mid-sixties. However, the textbook's impact is not only quantitative: past contributions have also emphasized Samuelson's role in disseminating "the textbook Keynesian model" and the consolidation of the "neoclassical synthesis", a term Samuelson coined in the third edition (Pearce and Hoover 1995). Subsequent textbooks did not just borrow the theoretical content of Economics, but its pedagogical approach and mode of presentation. David Colander (2012) even calls the current textbook age in economics "the Samuelsonian era", claiming that it "became the template for almost all key books after that up until 2010" (Colander 2012, p. 324). According to him, the subsequent decline in sales did not undermine its influence on today's leading textbooks, which, he argues, are still following its path "even though economics has changed considerably in the interim" (p. 337). The result in his view is a widening gap between what economists do and what they teach.

\section{Textbooks as proxies for the economics discipline's prejudices}

Even though Colander's piece is not downright critical of mainstream economics, his remark on the textbooks lagging behind research is indicative of the normative attitude a number of contributors have when they study textbooks, the latter being used as proxies for the many biases of mainstream economics and its tardiness to reform itself. Although historically informed, these contributions are most often authored by practitioners who have a strong interest in economics education or are members of communities that defend traditions alternative to the dominant neoclassical framework. This is the case of Colander who, in addition to his historical work, is also the author of several introductory textbooks whose approaches are overtly critical of the standard literature. What is not clear, however, in these accounts, is whether textbooks are inherently conservative because of their passive character or if textbook authors and other forces such as the publishing market or larger education policies have been active in maintaining the status quo. In another contribution, Colander and two co-authors make it more explicit that their views on textbooks are borrowed from Kuhn, therefore ranging with the "passive" camp. Their piece argues that mainstream economics is no longer the unified framework most people believe it is but that its evolution into a more pluralistic endeavor, which is already effective "at the edge" of the discipline, is slowed down by textbooks. Here, the authors write: "The process from conception of an idea to its appearance in graduate textbooks can take up to ten years. Intermediate and upper level undergraduate textbooks usually take another five to ten years to include these ideas... Principles books take another five to ten years to actually incorporate the idea as a central 
element, although, like their undergraduate upper level counterparts, they may add them as addenda so that they look modern...Consequently, textbooks, especially lower level texts, often do not reflect the diversity of views acceptable to the mainstream, but instead reflect an older orthodox position (Colander et al. 2004: 494-5)". This account, however, would require further investigation into the editorial process and the market for economics education to be completely convincing.

Other similarly critical contributions, however, seem to assume authorial intent, implying that some textbook authors have been active in trying to slow down progress in economics. Two examples of this historiographical genre are particularly striking. Nelson 2001, which places itself in Deirdre McCloskey's rhetorical approach, argues that mainstream economics, as exemplified among other works in Samuelson's Economics, acts more like religion than science, having 'faith' in the market mechanism and 'preaching' scientific management of the economy. Nelson claims, not erroneously so, that Samuelson is as much an heir of late nineteenth century American progressives, who were deep into the social Gospel of their time, than of Keynes. Nelson makes this claim by looking at the wording used in the textbook. "From time to time", he writes, "Samuelson drops his posture of scientific neutrality and adopts an explicitly moralistic tone that more accurately conveys his fundamental values. At one point in Economics, for example, he says that the current unequal distribution of income in the United States is 'improper' and in fact an outright 'evil' ... Monopolistic practices by which the powerful exploit the weak are another 'evil.' Indeed, the use of the term evil occurs with surprising frequently throughout the pages of Economics." Another instance is Levy and Peart 2009, which uses different textbooks - by Samuelson, Campbell McConnell, Leland Bach, Lorie Tarshis and Robert Heilbronner - to study how they treat the issue of Soviet growth through several editions. They show that all textbooks overestimated Soviet growth, claiming that its GNP could catch up with that of the United States. Levy and Peart argue that this manipulation betrays, not the authors' ideological prejudices, but their methodological ones, namely their overconfidence in models of prediction relying on the production possibilities frontier. These contributions, too, have underlying methodological premises, sometimes quite unthinkingly. First, they assume that because textbooks are more likely made of verbal assertions as opposed to the mathematical research dominating in the discipline, looking at them could help identify beliefs that are usually obscured by the technique. Second, they often focus on textbooks written by relatively well-known figures because they believe that their views and biases are symptomatic of the views and biases of some subset of the economics profession. In the end, there is something 
relatively paradoxical about this genre of analysis, which simultaneously expects textbooks to cope with recent research - as passive recording devices do - and, nonetheless, pays attention to an author's idiosyncrasies, adopting therefore a more active view of textbooks. These accounts would be more convincing if they included a deeper enquiry on the textbook authors' motivations and their limitation in view of all the other factors that influence textbook making.

\section{Textbooks in studies of dissemination}

In his historiographical account, Simon (2016) argues that studies in dissemination - i.e. studies that retrace the development of a concept through successive editions of a sample of textbooks throughout over a given period - often dominate disciplinary histories of scientific textbooks and it is true that there is a fair number of those in our field, even these are more easily found in student's essays or master theses than in articles published in peer-reviewed journals. Indeed, studies in dissemination are rather unlikely to fully convince referees because most of the times they are subject to too much questioning. How are we sure that the sample of textbooks that has been surveyed is sufficiently representative of the profession? Why did the author ignore the context of publication of such or such textbook? Are the results observed explained by changes in the profession or are they more affected by publishing market issues? Most of the time, the essay will conclude that there is a "time lag" between research and teaching, therefore falling into the "diffusion model" that historians of science are so eager to get rid of. Yet, studies in dissemination through textbooks can be satisfying on certain occasions, for instance when textbook authors were themselves involved in the development of the concepts they help disperse through textbooks. James Forder's recent study of the Phillips curve - the statistical curve showing a decreasing relationship between wage increase and unemployment then turned into a theoretical relationship between unemployment and inflation - in introductory textbooks (Forder 2015) indeed involves Samuelson and Lipsey, two major players both in textbook writing and in the development of the curve itself - both gave the curve its standard interpretation in two separate contributions published in 1960. In addition, Samuelson's Economics and Lipsey's An Introduction to Positive Economcs had several editions over the period under scrutiny, which allows for comparisons between editions. Forder's main use of the textbook literature is to show that the view that the Phillips curve was used as a plea for inflationary economic policies, spread in recent textbooks, is a distortion of what was actually published in older texts. Yet, Forder 
makes it clear that he does not consider his paper as a contribution to textbook history, whose specific role in constructing "the Phillips curve myth" he does not discuss. Textbooks, therefore, do not appear as different as other sorts of treatises and the only reason why they are informative in this case is because their authors are of a sufficient stature that we can assume authorial intent.

The work recently undertaken by Steven Medema on the dissemination of the Coase theorem through textbooks is another instance of a compelling dissemination study. Medema had already used textbooks in the study he wrote with Roger Backhouse on the evolving definition of economics (Backhouse and Medema 2009) and, unlike most historians of economics, he is familiar with the current historiography of scientific textbooks, on which he reflected in a previous contribution (Medema 2012) In this piece, which is a transcript of his 2011 Blanqui lecture, Medema argues that using "textbooks as data" does not necessarily mean that they should be considered as passive recording devices of past economics. Citing Bensaude Vincent et al.'s works on the history of chemistry textbooks, Medema stresses that textbooks play a crucial role in the making of normal science, the latter being no less worthy of attention than its revolutionary counterpart and warns fellow historians against the temptation to treat textbooks in a critical, retrospective way, even arguing that as increasingly standardized items, they tend to be the best proxies of the assimilation of one specific idea or technique. He adds that textbooks can be used in order to tell stories of science education and mass communication. As the lecture turns more specifically to the issue of how the Coase theorem was incorporated into the textbook literature, Medema claims that misinterpretations of Coase's original intent do not matter from a historical point of view. What matters, however, is why such deviations from the original 'theorem' occur. Medema, therefore, lists several reasons: some that are related to pedagogical concerns and some which he relates to the author's stances, either personal or reflecting his affiliation. Because of its quite general scope, the lecture does not really detail the textbook literature. That is done in a subsequent working paper (Medema 2014) devoted to the dissemination of the theorem in intermediate microeconomics textbooks. Here, the author studies in detail 48 textbooks published between 1960 - the year of publication of Coase's "The Problem of Social Cost" - to 1979. Using a relatively exhaustive number of US texts means that textbooks written by relatively authoritative figures such as George Stigler are treated along with lesser-known authors. Just like Kaiser's study of the dispersion of Feynman diagrams, Medema's textbook analysis shows many different variants of the Coase theorem. Medema's main finding is that while Coase's use of the theorem was mostly theoretical, it is presented in these textbooks in ways 
that makes it more suited to the treatment of environmental issues. His interpretation is that textbooks are more interested in practical applications of the theorem because their authors want to keep the students interested. The paper, therefore, argues that textbooks have played a role in making the Coase theorem a staple of environmental economics.

\section{Textbooks within an economist's life}

Another way in which textbooks are introduced in the history of recent economics is in monographs and biographical accounts. There are generally thick histories - relying on archival materials - even though their main intent was not necessarily to reflect on textbooks per se. Here, again, studies on Samuelson's textbook clearly prevail. The MIT economist himself wrote an autobiographical piece on the textbook (Samuelson 1997) in response to one of his critics (Skouzen 1997) using anecdotes to do so - Samuelson's own historiographical approach when dealing with contemporary economics (see Weintraub 2016a). Following the arrival of Samuelson's personal papers at Duke in 2011, narratives about the birth and development of the textbook, which are not weighed down by its author's attempts to protect his legacy, have been written. Backhouse (2017a)'s biography of Samuelson, which ends with the publication of the first edition of Economics, clearly points to the textbook, along with the theoretical contribution Foundations of Economic Analysis published a year before, as the touchstone of modern economics. But claiming this would not differ from Samuelson's own claim if it was not accompanied by another claim: that the textbook also played a more intimate role in Samuelson's life career, namely to allow him to "become Samuelson". The textbook presented a public face of the author that was not contained in his academic papers, that of a 'applied macroeconomist', following his participation in the National Resources Planning Board during WWII and his writing articles on policy in the New Republic. Economics' allegedly Keynesian bent was influenced by these war and postwar experiences, as well as by the proximity to Harvard Professor Alvin Hansen, more so than by an allegiance to Keynes' own writing. When the textbook was received with controversies, mostly coming from the anti-Roosevelt, right-wing industrial milieu, Samuelson sought to deter criticisms by softening the textbook's relatively political overtone and by pretending that he had never been a true Keynesian, thus constructing a somewhat ambiguous middle-of-the-road position (see also Giraud 2014). Looking at the textbook through the influence of Hansen, Backhouse shows that the textbook was not solely intended as a principles text. Although it served specific purposes at MIT - training future engineers with little interest in economics - it was 
also conceived as an intellectual contribution to public finance, while Hansen and other socalled Keynesians were doing the same in more conventional treatise form.

Moving away from the first edition also brings useful information to understand the textbook. In a recent paper, Backhouse (2017b) reasserts that the textbook is not just a pedagogical device but also Samuelson's main contribution to policy issues, even more so than his pieces in newspapers and magazines. Samuelson even used materials prepared for the fifth edition of his textbook to advise the Senator John Kennedy. Not unlike the story told in Kaiser 2012 for postwar physics textbooks, this story illustrates how fluid is the textbook status and how a piece conceived for the classroom can also serve other purposes. Similarly, Giraud 2017 explores the role of Economics in the late 1960s and early 1970s, showing how the textbook was revised in order to respond to attacks from younger radical economists. The story told is not just one involving ideological divergences in the economics profession, but also sheds light on how an increasingly competitive textbook market influenced the textbook in its period of maturity. Facing criticisms but also the emergence of a new generation of textbooks, such as McConnell or Richard Lipsey, Samuelson is forced to introduce numerous changes in-between editions and is helped for this purpose by his editorial team at McGrawHill. The book that bears his name is still pretty much his own but following the authors' unwillingness to do these revisions from the late 1970s onward, it slowly transforms into a franchise. The standardization of postwar textbooks, therefore, is not just the story of all of the textbooks resembling more to Samuelson's but one of mutual stabilization. Thicker accounts of textbooks, therefore, are an invitation to reconsider the line between authorial intent and external constraints.

J.E. King and Alex Millmow's account of Joan Robinson and John Eatwell's An Introduction to Modern Economics, the only monographic contribution to textbooks not dealing with Samuelson's constitutes a welcome counterpoint, and not just because Robinson was known as one of mainstream economics' most ardent critics. Robinson's textbook was indeed intended as an alternative to Samuelson and to other leading American texts of the time -interestingly, it was also published by McGraw-Hill - but the authors' depiction of its stinging failure to do so tells us something about how textbooks work. While both Giraud (2010, 2014) and Backhouse (2017a) emphasize that Economics arose from pedagogical issues, namely the necessity to teach engineering undergrads at MIT, King and Millnow observe that neither Robinson nor Eatwell had taught an introductory class. As a result, the textbook structure and content were solely driven by its authors' theoretical bent when those of Economics reflected both theoretical positions and educational concerns. Whereas 
Samuelson accepted to revise his manuscript in order to deter early criticisms, and would go on doing so edition after edition, Robinson's stubbornness generated numerous tensions with the team of students and staff who were supposed to advise her on and whose ideas she most often rejected. McGraw-Hill eventually refused to release the book in the United States as it was deemed unsuitable for American undergraduate students. As King and Millnow observe at some point in their narrative, Robinson and Eatwell's book simply lacked the "feel" of an actual textbook. The paper convincingly conveys that textbooks can only work within certain pedagogical practices. It is not so much the dissenting character of Robinson and Eatwell's text that explains its lack of success but the fact that they tried to write a textbook without much introductory teaching experience, as opposed to Samuelson's ability, not just to convey the Keynesian revolution, but also to address students' concerns.

\section{Textbooks and departments}

The recent shift in the focus of historians of economics from the study of individuals to that of creative communities (Forget and Goodwin 2011) has produced a few enlightening accounts of economics departments in the postwar period, some of which show that textbooks have played a role in creating a sense of community inside these institutions or an image towards outsiders. Two departments in particular have been studied: MIT and the Chicago School.

As it is well known, there was not anything like an identifiable economics department at MIT before the arrival of Paul Samuelson whose textbook Economics served first and foremost as a tool to teach economics principles and policies to future engineers but soon contributed to promoting MIT economics as whole. As Harro Maas (2014) argued, what made the textbook so controversial in its first years was how it was expected to present an image of MIT to a broader audience. Conservative critics often claimed that Samuelson's alleged leftwing bent would be detrimental to the Institute's notoriety as a serious, apolitical, engineering school. In response to these attacks, Samuelson carefully constructed a middle-of-the-road position through the textbook and promoted it in various leaflets and press interviews that helped strengthen the reputation of the department as a purveyor of balanced, technical economics expertise. Expanding the study beyond Samuelson's case, Pedro Teixeira (2014) shows that MIT economists have had "significant involvement with the production of textbooks". He identifies seventy-two textbooks written by thirty-nine economists who have studied or taught at MIT in the postwar period, contributing to teaching and research at the undergraduate and graduate levels. These textbooks did not only reflect MIT's focus on 
teaching - which was important in the first decades following WWII - but its commitment to technicality and generality - MIT economists wrote few specialized graduate texts and rather focused on microeconomics, macroeconomics and mathematical and quantitative methods.

Textbooks played a role at the University of Chicago as well. Although written when George Stigler was at Columbia, his graduate text The Theory of Competitive Price (1942), later republished with additional materials as The Theory of Price (1946), along with other practices such as the Chicago workshop, was essential in disseminating the "Chicago Price Theory Tradition" (Medema 2011). Using an alteration of Robbins' definition of economics as "the allocation of scarce means among competing ends", Stigler paved the way for the kind of economic analysis of non-economic problems the Chicago School became famous for - for instance, Becker's economic approach to or Posner's economic analysis of law. Jean-Baptiste Fleury (2012) explores a different kind of textbook literature, one that stands at the crossroads between academic writing and popular economics, the "economics-made-fun movement", represented today by Chicago economist Steven Levitt's best seller Freakonomics. Fleury shows that Levitt's highly popular book is only the latest instantiation of a sort of text that applied economic analysis to a range of everyday problems. One of its predecessors was Richard McKenzie and Gordon Tullock's The New World of Economics - Tullock was a former student at the University of Chicago -, which resembled Levitt's, although its targeted audience were undergraduate and graduate students, rather than the public at large. These textbooks arose from pedagogical debates happening in the 1960s, when economics education suffered a crisis of 'relevance' and principles text like Samuelson's were deemed unsuitable for the issues of the day. Like Kaiser's piece on physics textbooks, Fleury's article is a good example of how flexible the frontier between academic texts and popular books can be (see Mata, this volume).

The existing literature on this topic is still fragmentary but more should be expected when historians of economics expand their studies to other economics departments or to the study of economics taught in social science departments or engineering schools.

\section{Towards better and thicker histories of economics textbooks}

As the above sections hopefully conveyed, there is much more to historical studies of economics textbooks than depictions of how textbooks lag behind the latest advances in economics research or studies in the dissemination of economics concepts. Yet even the latter, if done properly, can yield important results, showing how textbooks do not just disseminate 
knowledge, but by altering it, contribute to create new meanings and uses of preexisting economics ideas. An accurate account of how textbooks disperse and affect knowledge requires a lot of research in order to build a good database of textbooks to analyze. When Steven Medema began his research on this subject, he did not have much accumulated knowledge to rely on. ${ }^{7}$ There is still some progress to be made on this side of economics textbook research. While individual authors like Medema have been able to assemble large personal collections of textbooks in order to substantiate their accounts, there has been, to the best of my knowledge, no attempt at building a list of the most popular undergraduate and graduate textbooks over time. To build such a list would require to cross-check a great number of reading lists in departmental archives. This can be helped by the use of some publishers' reports, containing detailed studies of available textbooks at a certain point in time. Some of McGraw-Hill reports are found in the Samuelson archives at Duke University. They contain some sales figures as well as a list of institutions using such or such textbook. These documents are necessarily fragmentary and are rarely available over the long period, yet even a fragmentary or incomplete list would help. Besides, the kind of digital collection Irwin Collier has assembled for economics departments' curriculums would be equally useful for textbooks. ${ }^{8}$ There are of course a number of factors limiting such endeavors. Copyright is one of them: whereas some prewar textbooks are easily findable on websites such as archive.org, postwar texts still fall, for the most, under copyright laws. Another limitation is that building a textbook collection, while useful for further research, is rarely seen as wellspent research time. When many members of the community still see textbooks as low-status items, as opposed to research articles one can now easily find on databases such as JStor or EconLit with Full Text, it is not easy to convince funding agencies that such undertaking is vital to the understanding of how economics works. However, we can hope that in the near future, a more systematic recourse to blogs and social networks could help gather more information on textbooks.

Beyond studies in dissemination, there is a vast horizon for future research. What we need are studies that look further than Samuelson's Economics and focus on lesser-known

\footnotetext{
${ }^{7}$ A query he posted on our profession's main mailing list to look for the most popular textbooks of the 1970s and 1980s yielded little useful information. See "SHOE: QUERY--The Relative Popularity of Economics Textbooks in the 1970s and 1980s" and responses, Archives of SHOE@YORKU.CA Societies for the History of Economics, available at https://listserv.yorku.ca/archives/shoe.html (last accessed October 10th 2017).

8 Economics from the rear-view mirror: archival artifacts from the history of economics, http://www.irwincollier.com/ (last accessed October $6^{\text {th }}, 2017$ ). See his chapter in the volume as well.
} 
authors such as McConnell, Bach or Heilbronner for instance. The economic journalist and textbook author Leonard Silk, whose archives are also located in the Economists' Papers collection, could be an interesting case study. A closer look at the story behind the making of Lipsey's An Introduction to Positive Economics and its North-American counterpart Lipsey and Peter Steiner's Economics could offer an interesting view in the changing textbook cultures on each part of the Atlantic. Moreover, echoing Simon 2016's concerns with the overrepresentation of American and European science in existing historical accounts, future studies should also focus more on textbooks published in other parts of the world and in texts not initially published in English. This could help enlighten the role of scientific education and reveal specific scientific policies concerns in developing and peripheral countries, for instance. Studies of translations of American texts would also offer interesting cases of dispersion, offering more accurate studies of standardization - or lack thereof - in postwar economics. They would certainly highlight the role of figures that were neglected in the current historiography, not only textbook authors but also translators of British and NorthAmerican texts.

One importance deficiency of the existing literature, which we already spotted earlier in this chapter, is the lack of studies focusing on graduate textbooks. It is now well established that a number of economic traditions in the postwar period have been associated with the creation of successful graduate programs. François Claveau and Yves Gingras' (2016) recent bibliometric analysis of the formation of economic specialties in the recent period points to graduate texts such as Jean Tirole's The Theory of Industrial Organization (1988) or Olivier Blanchard and Stanley Fischer's Lectures on Macroeconomics (1989) as some of the most cited references in fields their authors often contributed to create or develop. The genesis of these texts, their uses in their respective specialties for teaching and research purposes need to be put better studied. Granted, this would require from the historian's side more openness to the sophistication of recent economics, while studies of undergraduate texts do not require much mathematical proficiency.

On a final note, I would like tell a personal anecdote about textbooks that reminds me of the Cold Case story. The first textbook I bought for historical purposes was Frederic Garver and Alvin Hansen's Principles of Economics (1928). My interest in this was that it seemed to have been one of the most popular textbooks when Samuelson was a student. As it is often the case with used copies of textbooks, mine came with a number of notations in pencil and underlining to the text. On the fore edge, it had "AGE" written with a pen, an acronym for Avis, Genella and Eve, as a handwritten note on the free front page made clear. 


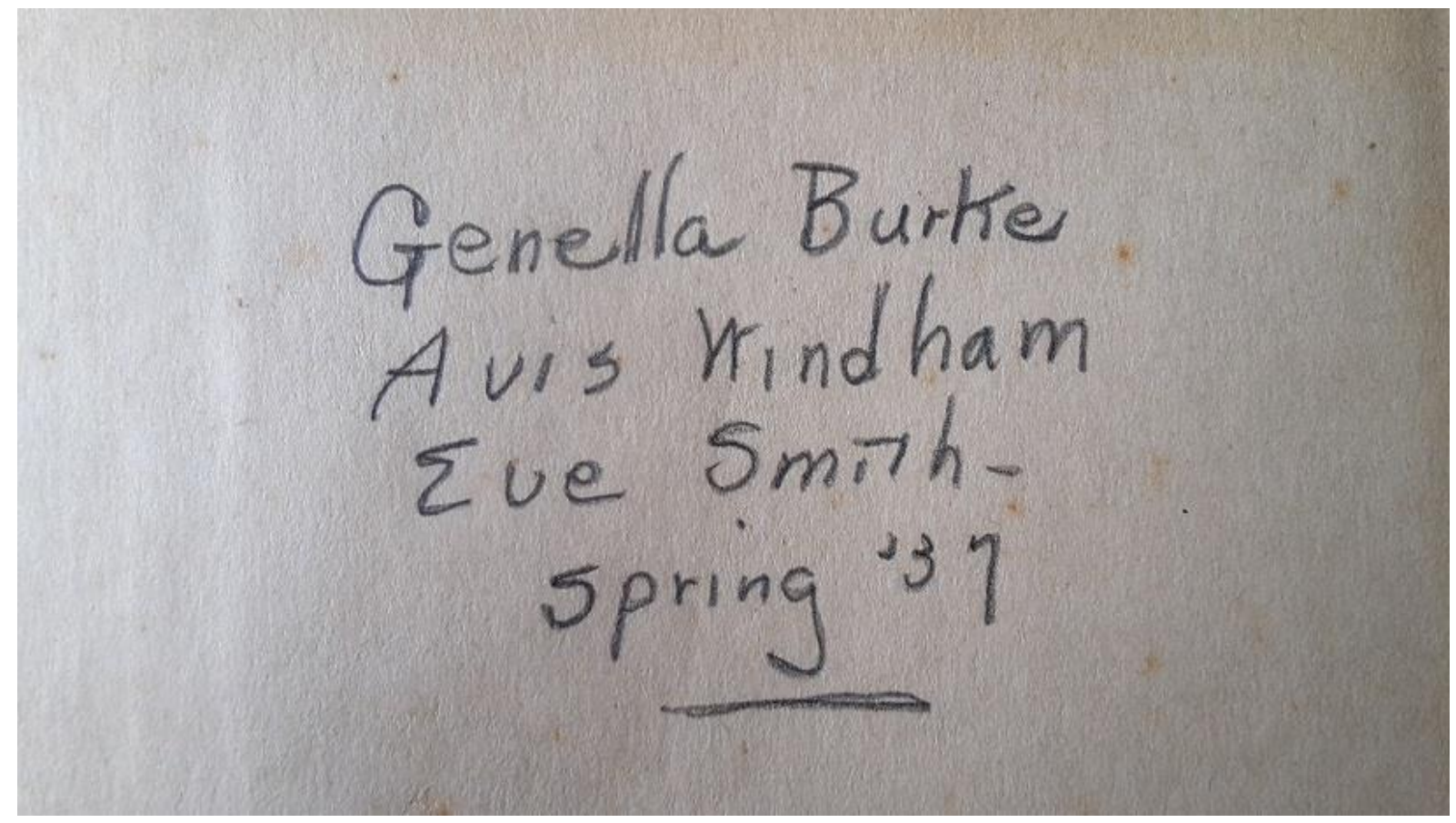

Who were Genella Burke, Avis Windham and Eve Smith, who bought this book in the Spring of 1937? Were they pursuing a degree in economics or were they studying economics as part of a more general curriculum? They may have attended a women's college but they may as well have bought it for the sake of intellectual curiosity. I will probably never clear that out. I have tried to look for more elements but they are few and quite uncertain to start with. Having bought this through an online seller and having no clue about the location of the used books store does not make it easy. There is an obituary record for a Genella Burke, who died at the age of 87 in 2005 in Birmingham, Alabama, and a few Avis Windham who could match the note - Eve Smith, on the other hand, may be too generic a name to find, but all of this proved to be much too meager to be followed seriously. Yet, that handwritten note on an old textbook helps envision a different kind of economics textbook history, one that is written, not from the point of view of their authors, but from that of the 'ordinary' people for whom economics education was intended in the first place. Other historiographical techniques depicted in this volume can help write such histories and, hopefully, more 'cold cases' will soon be solved. 


\section{References}

Augello, Massimo M. and Marco E. L. Guidi, eds. (2012). The Economic Reader: Textbooks, Manuals and the Dissemination of the Economic Sciences during the 19th and Early 20th Centuries. London, UK: Routledge.

Backhouse, Roger E. (2017a). Founder of Modern Economics: Paul A. Samuelson. Volume 1: Becoming Samuelson, 1915-1948. Oxford, UK: Oxford University Press. (2017b). "Samuelson and Kennedy: Textbook author as policy adviser." Working Paper (Preliminary draft, March 2017).

Backhouse, Roger and Steven G. Medema (2009). "On the Definition of Economics.” Journal of Economic Perspectives, 23 (1): 221-33.

Bensaude-Vincent, Bernadette, Antonio Garcia-Belmar and José R. Bortomieu-Sanchez. (2003). La naissance d'une science des manuels (1789-1852). Paris, FR : Edition des Archives Contemporaines.

Charles, Loïc (2008). "The Icon." Blog entry. https://historyofeconomics.wordpress.com/2008/09/26/the-icon/ (last accessed, February $\left.9^{\text {th }}, 2018\right)$.

Claveau, François and Yves Gingras (2016). "Macrodynamics of Economics: A Bibliometric History." History of Political Economy, 48 (4): 551-92.

Colander, David (2012). "The Evolution of US Economics textbooks." In The Economic Reader, edited by M. Augello and M. Guidi, 324-39. London, UK: Routledge.

Colander, David, Richard Holt b \& Barkley Rosser Jr. (2004). "The Changing Face of Mainstream Economics." Review of Political Economy, 16 (4): 485-99.

Elzinga, Kenneth G. (1992). "Eleven Principles of Economics.” Southern Economic Journal, 58 (4): 861-79.

Fleury, Jean-Baptiste (2012). "The evolving notion of relevance: an historical perspective to the 'economics made fun' movement." Journal of Economic Methodology, 19 (3): 303-16.

Fontaine, Philippe (2016). "Other Histories of Recent Economics: A Survey." History of Political Economy, 48 (3): 373-421.

Forder, James (2015). "Textbooks on the Phillips Curve." History of Political Economy, 47(2): 207-24.

Forget, Evelyn L. \& Craufurd D. Goodwin (2011). "Intellectual Communities in the History of Economics." History of Political Economy, 43 (1): 1-23. 
Giraud, Yann (2010). “The Changing Place of Visual Representation in Economics: Paul Samuelson between Principle and Strategy, 1941-1955." Journal of the History of Economic Thought, 32 (2): 175-97.

(2011). "A Cold Case." Blog entry.

https://www.ineteconomics.org/perspectives/blog/a-cold-case (last accessed February $\left.9^{\text {th }}, 2018\right)$.

(2014). 'Negotiating the 'Middle-of-the-Road' Position: Paul Samuelson, MIT and the

Politics of Textbook Writing, 1945-55." History of Political Economy, 46 (Supplement): 134-52.

(2017). "The Contestable Marketplace of Ideas: Paul Samuelson's Defense of Mainstream Economics Through Textbook Making, 1967-1976”. Working paper, https://papers.ssrn.com/sol3/papers.cfm?abstract_id=3009252 (last accessed July $26^{\text {th }}$, 2017).

Kaiser, David (2005). Drawing Theories Apart: The Dispersion of Feynman Diagrams in Postwar Physics. Chicago, IL: The University of Chicago Press. (2012). “A Tale of Two Textbooks: Experiments in Genre.” Isis, 103 (1): 126-138.

Kuhn, Thomas, 1977 [1959], "The essential tension: Tradition and innovation in scientific research." In The Essential Tension: Selected Studies in Scientific Tradition and Change, 225-39. Chicago, University of Chicago Press.

Latour, Bruno (1987). Science in Action. Cambridge, MA: Harvard University Press.

Levy, David M. and Sandra J. Peart (2009). "Soviet Growth and American Textbooks." Working paper, http://ssrn.com/abstract=1517983 (last accessed June 29 ${ }^{\text {th }}$, 2017).

Lundgren, Anders and Bernadette Bensaude-Vincent, eds. (2000). Communicating Chemistry: Textbooks and Their Audiences, 1789-1939. Canton, MA: Science History Publications.

Maas, Harro (2014). "Making Things Technical: Samuelson at MIT." History of Political Economy, 46 (Supplement): 272-294.

Medema, Steven G. (2011). "Chicago Price Theory and Chicago Law and Economics: a Tale of Two Transitions." In Building Chicago Economics: New Perspectives on the History of America's Most Powerful Economics Program, edited by Robert van Horn, Philip Mirowski and Thomas Stapleford, 151-79. Cambridge, UK: Cambridge University Press. 
Read more at http://www.cambridge.org/fr/academic/subjects/economics/history-economicthought-and-methodology/building-chicago-economics-new-perspectives-historyamericas-most-powerful-economics-program\#ri5rSBY88jbyJF6u.99 (2012). "Textbooks as Data for the Study of the History of Economics: Lowly Beast or Fruitful Vineyard?" History of Economic Thought and Policy, 2: 193-207. (2014). "How Textbooks Create Knowledge and Meaning: The Case of the Coase Theorem in Intermediate Microeconomics." Working paper, https://papers.ssrn.com/sol3/papers.cfm?abstract_id=2479732 (last accessed June $29^{\text {th }}$, 2017).

Nelson, Robert H. (2001). Economics as Religion: From Samuelson to Chicago and Beyond. University Park, PA: Pennsylvania State University Press.

Patiniotis, Manolis (2006). "Textbooks at the Crossroads: Scientific and Philosophical Textbooks in $18^{\text {th }}$ Century Greek Education." Science and Education, 15: 801-22.

Pearce, Kerry A. and Kevin D. Hoover (1995). "After the Revolution: Paul Samuelson and the Textbook Keynesian Model." History of Political Economy, 27(Supplement): 183216

Simon, Josep (2016). “Textbooks." In A Companion to the History of Science, edited by Bernard Lightman, 400-13. Chichester, UK: John Willey and Sons.

Samuelson, Paul A. (1998). "Credo of a Lucky Textbook Author." Journal of Economic Perspectives, 11 (2): 153-60.

Rocke, Alan J. (2010). Image and Reality: Kekilé, Kopp and the Scientific Imagination. Chicago, IL: The University of Chicago Press.

Skousen, Mark (1997). “The Perseverance of Paul Samuelson's Economics.” Journal of Economic Perspectives, 11 (2): 137-52.

Teixeira, Pedro (2014). "Serving the Institute and the Discipline: The Changing Profile of Economics at MIT as Viewed from Textbooks." History of Political Economy, 46 (Supplement): 153-74.

Vicedo, Marga (2012). "Introduction: The Secret Lives of Textbooks". Isis, 103 (1): 83-7.

Weintraub E. Roy (2016a). "Paul Samuelson's Historiography: More Wag than Whig." History of Political Economy, 48 (2): 349-363. (2016b). Game Theory and Cold War Rationality: A Review Essay. Economic Research Initiatives at Duke (ERID) Working Paper No. 208, https://ssrn.com/abstract=2737005 (last accessed October $4^{\text {th }}, 2017$ ). 